Article

\title{
Environmental and Genetic Determinants of Serum 25(OH)-Vitamin D Levels during Pregnancy and Early Childhood
}

\author{
Ann-Marie Malby Schoos ${ }^{+}\left(\mathbb{D}\right.$, , Cecilie Vinther ${ }^{\dagger}$, Sarah Nørgaard, Nicklas Brustad, \\ Jakob Stokholm ${ }^{D}$, Klaus Bønnelykke, Hans Bisgaard * and Bo Lund Chawes ${ }^{\mathbb{D}}$ \\ COPSAC, Copenhagen Prospective Studies on Asthma in Childhood, Herlev and Gentofte Hospital, \\ University of Copenhagen, 2820 Gentofte, Copenhagen, Denmark; ann-marie.schoos@dbac.dk (A.-M.M.S.); \\ cevinther@gmail.com (C.V.); sarah.noergaard@dbac.dk (S.N.); nicklas.brustad@dbac.dk (N.B.); \\ stokholm@copsac.com (J.S.); kb@copsac.com (K.B.); chawes@copsac.com (B.L.C.) \\ * Correspondence: bisgaard@copsac.com \\ † joint first authors (both contributed equally).
}

Received: 17 September 2019; Accepted: 16 October 2019; Published: 21 October 2019

\begin{abstract}
Vitamin D insufficiency has become a common health problem worldwide, particularly among pregnant women and young children. Therefore, we sought to identify environmental, dietary, and genetic determinants of serum $25(\mathrm{OH})$-vitamin $\mathrm{D}(25(\mathrm{OH}) \mathrm{D})$ levels during pregnancy and early childhood. $25(\mathrm{OH}) \mathrm{D}$ was measured in women at 24-weeks of gestation $(n=738)$ and one-week postpartum $(n=284)$ in the population-based Danish COPSAC 2010 mother-child cohort; and in cord blood $(n=257)$ and age 4 years $(n=298)$ in children from the at-risk COPSAC 2000 mother-child cohort. Environmental, dietary, and genetic variables were tested for association with $25(\mathrm{OH}) \mathrm{D}$ using linear regression analyses. After adjusting for season of blood sampling, determinants of lower 25(OH)D levels during pregnancy in the women were higher pre-pregnancy BMI, lower age at birth, lower genetic vitamin D score, lower dietary vitamin D intake, and lower social circumstances. In children, the determinants were lower maternal age at birth, higher pre-pregnancy BMI, lower genetic vitamin D score, older siblings, exposure to tobacco smoking, and female sex. Genetics was an important determinant at all time points, alone explaining $2 \%-11 \%$ of the variance in $25(\mathrm{OH}) \mathrm{D}$. Important determinants of circulating 25(OH)D levels during pregnancy and early childhood include environmental factors, diet, and to a large extent genetics.
\end{abstract}

Keywords: $\mathrm{MeSH}$; 25(OH)-vitamin D; vitamin D; determinants; genetics; environmental factors; pregnancy; children

\section{Introduction}

Humans get vitamin D from exposure to sunlight, diet, and dietary supplements. Dietary sources of vitamin D include oily fish, egg yolk, and fortified foods including milk, cheese, orange juice, infant milk formula, etc. [1]. Vitamin D deficiency affects bone mineralization and can lead to rickets, increased fracture risk, and osteoporosis [2], but has also been shown to associate with several non-communicable diseases including childhood asthma [3], diabetes [4], hypertension [5], cardiovascular events [6,7], obesity [8], cancer [9-14], and multiple sclerosis [15].

Circulating 25(OH)-vitamin D $(25(\mathrm{OH}) \mathrm{D})$ levels vary among humans, and according to the majority of single-center studies, vitamin D deficiency (defined as $25(\mathrm{OH}) \mathrm{D}$ of less than $50 \mathrm{nmol} / \mathrm{L}$ (20 $\mathrm{ng} / \mathrm{mL})$ [16-18]) is widespread in children, pregnant women, and breastfeeding mothers [19-22]. It has been estimated that vitamin D insufficiency, defined as $25(\mathrm{OH}) \mathrm{D}$ between 50 and $75 \mathrm{nmol} / \mathrm{L}$ 
(20-30 ng/mL) [16-18], affects as many as one-half of otherwise healthy adults in developed countries and that one billion people worldwide have vitamin D deficiency or insufficiency [1].

Both dietary and environmental factors are speculated to play a role in the development of low $25(\mathrm{OH}) \mathrm{D}[1,14,20]$, and we have previously shown that season of birth affected cord blood 25(OH)D [23]. Further, the high heritability of vitamin D insufficiency suggests that genetic determinants may also be important, and genome-wide association studies have replicated four genetic markers influencing 25(OH)D levels, including GC (encoding vitamin D binding protein), CYP2R1 (encoding a C-25 hydroxylase converting vitamin D3 to an active receptor ligand), as well as DHCR7 and NADSYN1 (both involved in cholesterol synthesis) [24-27]. The aim of this study was to identify environmental, dietary, and genetic determinants of vitamin D deficiency during pregnancy in the population-based Copenhagen Prospective Studies on Asthma in Childhood $\left(\right.$ COPSAC $\left._{2010}\right)$ mother-child cohort and during early childhood in the at-risk COPSAC $_{2000}$ cohort.

\section{Methods}

\subsection{Ethics}

The Copenhagen Ethics Committee (HKF 01-289/96; H-B-2008-093) and The Danish Data Protection Agency (2008-41-1754; 2015-41-3696) approved the study. Oral and written informed consent was obtained from all parents at enrolment.

\subsection{Study Populations}

COPSAC $_{2000}$ is a prospective at-risk birth cohort study of 411 children born to mothers with a history of asthma during 1998-2001 [28-30]. The children were enrolled at age 1 month and subsequently attended 6-monthly visits to the COPSAC research unit until age 3 and yearly thereafter until age 7.

COPSAC $_{2010}$ is a prospective population-based mother-child cohort of 743 mothers and their 700 children recruited during 2009-2010 [31-33]. The women were included during pregnancy week 24. Exclusion criteria were gestational age above week 26, intake of vitamin D exceeding $600 \mathrm{IU} / \mathrm{d}$, or any endocrine/heart/kidney disorders. Of the included women, 623 were enrolled in a double-blind randomized clinical trial of $2400 \mathrm{IU} / \mathrm{d}$ cholecalciferol D3 supplementation or placebo (Camette, Denmark A/S) from pregnancy week 24 to one week postpartum. All participants were instructed to continue the recommended supplementation of $400 \mathrm{IU} / \mathrm{d}$ cholecalciferol D3.

\subsection{5(OH)D Measurements}

In COPSAC 2000 , serum 25(OH)D levels were measured at birth in cord blood and at 4 years of age. Cord blood was collected by needle puncture from the umbilical cord vein by midwives and subsequently sent to the COPSAC research unit. At age 4, a blood sample was collected from a peripheral vein at the COPSAC research unit. In COPSAC 2010 , maternal $25(\mathrm{OH}) \mathrm{D}$ levels were measured at week 24 of pregnancy and one week postpartum in blood samples collected at the COPSAC research unit. All the blood samples were centrifuged for $10 \mathrm{~min}$ at $4300 \mathrm{rpm}$ to separate serum and subsequently frozen at $-80^{\circ} \mathrm{C}$ until analysis, which was done by isotope dilution liquid chromatography-tandem mass spectrometry $[34,35]$ at the Dept. of Clinical Biochemistry, Aarhus University Hospital, Denmark. Further details are given in the Supplementary Materials.

\subsection{Determinants}

Anthropometry included child BMI at birth and age 4 years and maternal pre-pregnancy BMI. Length at birth was measured using an infantometer (Kiddimeter; Raven Equipment Ltd., Dunmow, Essex, England). Height at 4 years and maternal height was measured using a stadiometer (Harpenden; Holtain Ltd., Crymych, Dyfed, Wales). 
Environmental determinants included maternal age at birth; season of birth; gestational age at birth; smoking during third pregnancy trimester (yes/no); maternal asthma status during third trimester (better, unchanged, worse) for COPSAC 2000 and maternal asthma (yes/no) for COPSAC 2010 ; mode of delivery (natural/Caesarean section); and social circumstances based on household income, maternal age, and maternal educational level. Postnatal exposures included season of blood sampling (winter (December-February), spring (March-May), summer (June-August), and fall (September-November)), older siblings (yes/no), and environmental tobacco exposure measured objectively as hair nicotine level (ng/mg) at age 1 year [36]. Race and gender were included for all participants.

Diet in COPSAC 2010 included maternal mid-pregnancy dietary intake, obtained prospectively during a 4-week period by validated comprehensive food frequency questionnaires allowing for estimation of daily vitamin $D$ intake [37]. The child's dietary habit in COPSAC 2000 was only available in the first year of life, and therefore not used in the analyses.

Genetics included genome-wide genotyping data of the mothers and children in both cohorts. In COPSAC 2000 , a vitamin D genetic score was composed of GC, CYP2R1, DHCR7, and NADSYN1 genotype data, where the score is the number of effect alleles previously associated with an increase in 25(OH)D [24-26]. In COPSAC 2010 , the vitamin D genetic score was composed of two GC single nucleotide polymorphisms (SNPs) genotypes (rs4588 and rs7041) as the other SNPs used in COPSAC 2000 were not available in this cohort.

\subsection{Statistics}

Baseline characteristics are presented as median and interquartile range (IQR), mean and standard deviation (SD), or as number and percentage. Prior to analyses, the levels of 25(OH)D were adjusted for season by using a cosinus-sinus model $(25(\mathrm{OH}) \mathrm{D}=\sin (2 * \pi *$ day of blood sample/365.25) + $\cos \left(2^{*} \pi^{*}\right.$ day of blood sample/365.25)) as we wanted to examine determinants of 25(OH)D apart from the season of blood sampling. Thereafter, univariate linear regression models were used for crude analysis of the associations between the risk factors and $25(\mathrm{OH}) \mathrm{D}$ levels. Subsequently, multiple forward regression analyses were used as a variable selection method. The combination of variables that resulted in the lowest Akaike information criterion (AIC) determined the best model fit. Race was not included in the forward regression analysis, since genetic data were only obtained from Caucasians. Finally, multivariate regression analyses of all variables were performed. All statistical analyses were performed with RStudio version 3.3.0., considering a $p$-value $<0.05$ as significant.

\section{Results}

\subsection{Pregnant Women from $\mathrm{COPSAC}_{2010}$}

A blood sample was available for 25(OH)D analysis at pregnancy week 24 in $738(99 \%)$ of the 743 enrolled women and in 284 women at one week postpartum, who were randomized to placebo. The median (IQR) $25(\mathrm{OH}) \mathrm{D}$ level in the study group was $74.7 \mathrm{nmol} / \mathrm{L}$ (57-92) at pregnancy week 24 and $71 \mathrm{nmol} / \mathrm{L}$ (48-92) one week postpartum. At week 24 and one week postpartum, $14 \%$ and $22 \%$ of the women had deficient vitamin D levels $(<50 \mathrm{nmol} / \mathrm{L})$, respectively. Sufficient levels $(>75 \mathrm{nmol} / \mathrm{L})$ were measured in $52 \%$ of the women at week 24 and in $45 \%$ at one week postpartum. Baseline characteristics of the women are shown in Online Table S1.

In Figure 1, maternal 25(OH)D levels at gestational week 24 and one week postpartum are depicted, stratified for season of blood sampling and categorized into sufficient $(>75 \mathrm{nmol} / \mathrm{L})$, insufficient $(50-75 \mathrm{nmol} / \mathrm{L})$, and deficient $(<50 \mathrm{nmol} / \mathrm{L})$. At week $24,13 \%$ of the women had deficient $25(\mathrm{OH}) \mathrm{D}$ levels during summer compared to $17 \%, 10 \%$, and $14 \%$ during winter, spring, and autumn, respectively. Sufficient levels were measured in approximately half of the women $(40 \%-55 \%)$, with a slight preponderance during spring (55\%). At one week postpartum, slightly more women (19\%) had deficient $25(\mathrm{OH}) \mathrm{D}$ during summer compared to $21 \%, 21 \%$, and $26 \%$ during winter, spring, and autumn, respectively. Sufficient levels were measured in $41 \%-54 \%$ of the women. 


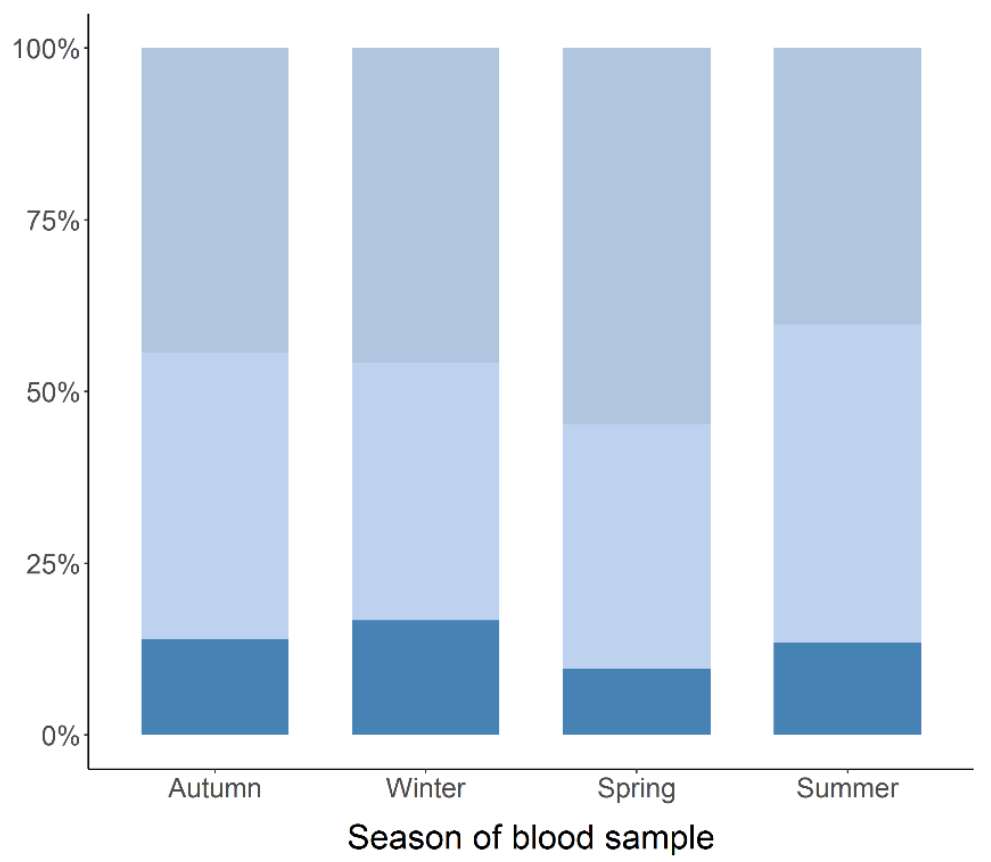

Vitamin D status

$>75 \mathrm{nmol} / \mathrm{L}$

$50-75 \mathrm{nmol} / \mathrm{L}$

$<50 \mathrm{nmol} / \mathrm{L}$

(A)

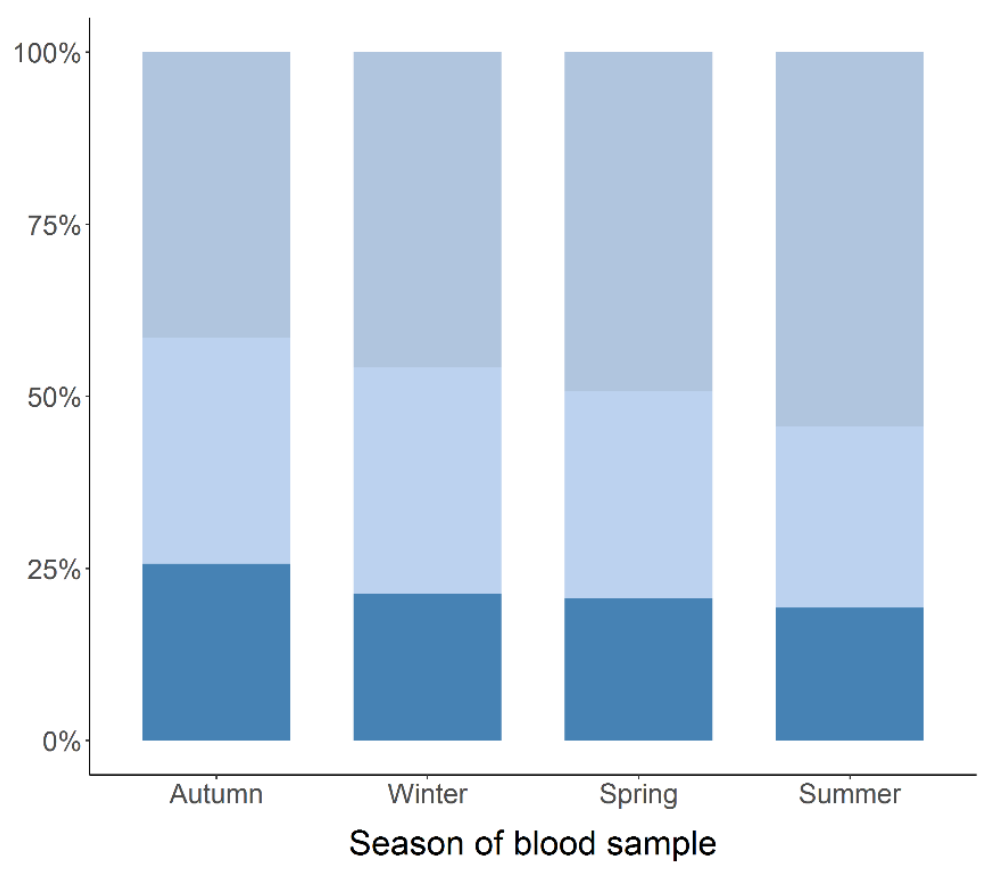

Vitamin D status

$>75 \mathrm{nmol} / \mathrm{L}$

$50-75 \mathrm{nmol} / \mathrm{L}$

$<50 \mathrm{nmol} / \mathrm{L}$

(B)

Figure 1. Maternal 25(OH)-vitamin D (25(OH)D) status (deficient $(<50 \mathrm{nmol} / \mathrm{L})$, insufficient (50-75 nmol/L), sufficient (>75 nmol/L)) at week 24 (A) and one week postpartum (B) stratified for season of blood sampling.

The absolute 25(OH)D levels varied significantly with season. For week 24 when using winter as reference, $25(\mathrm{OH}) \mathrm{D}$ was $19.3 \mathrm{nmol} / \mathrm{L}$ higher during summer $(95 \% \mathrm{CI}[14.2 ; 24.4], p<0.001)$ and $10.7 \mathrm{nmol} / \mathrm{L}$ higher during autumn $(95 \% \mathrm{CI}[6.0 ; 15.4], p<0.001)$. For one week postpartum, $25(\mathrm{OH}) \mathrm{D}$ was $27.2 \mathrm{nmol} / \mathrm{L}$ higher during summer vs. winter $(95 \%$ CI [17.3; 37.2], $p<0.001)$, but no significant differences were found for the rest of the seasons vs. winter. The 25(OH)D levels in week 24 and one week postpartum were associated both in the unadjusted and season-adjusted analyses: 0.54 (95\% CI 
[0.41; 0.67], $p<0.001)$ and $0.68(95 \%$ CI [0.56; 0.80], $p<0.001)$, respectively. We found no difference between the $25(\mathrm{OH}) \mathrm{D}$ levels at week 24 and one week postpartum: mean difference unadjusted was $-3.2 \mathrm{nmol} / \mathrm{L}(95 \% \mathrm{CI}[-6.9 ; 0.4])$ and adjusted was $0.4 \mathrm{nmol} / \mathrm{L}(95 \% \mathrm{CI}[-2.7 ; 3.5])$ (Figure 2).

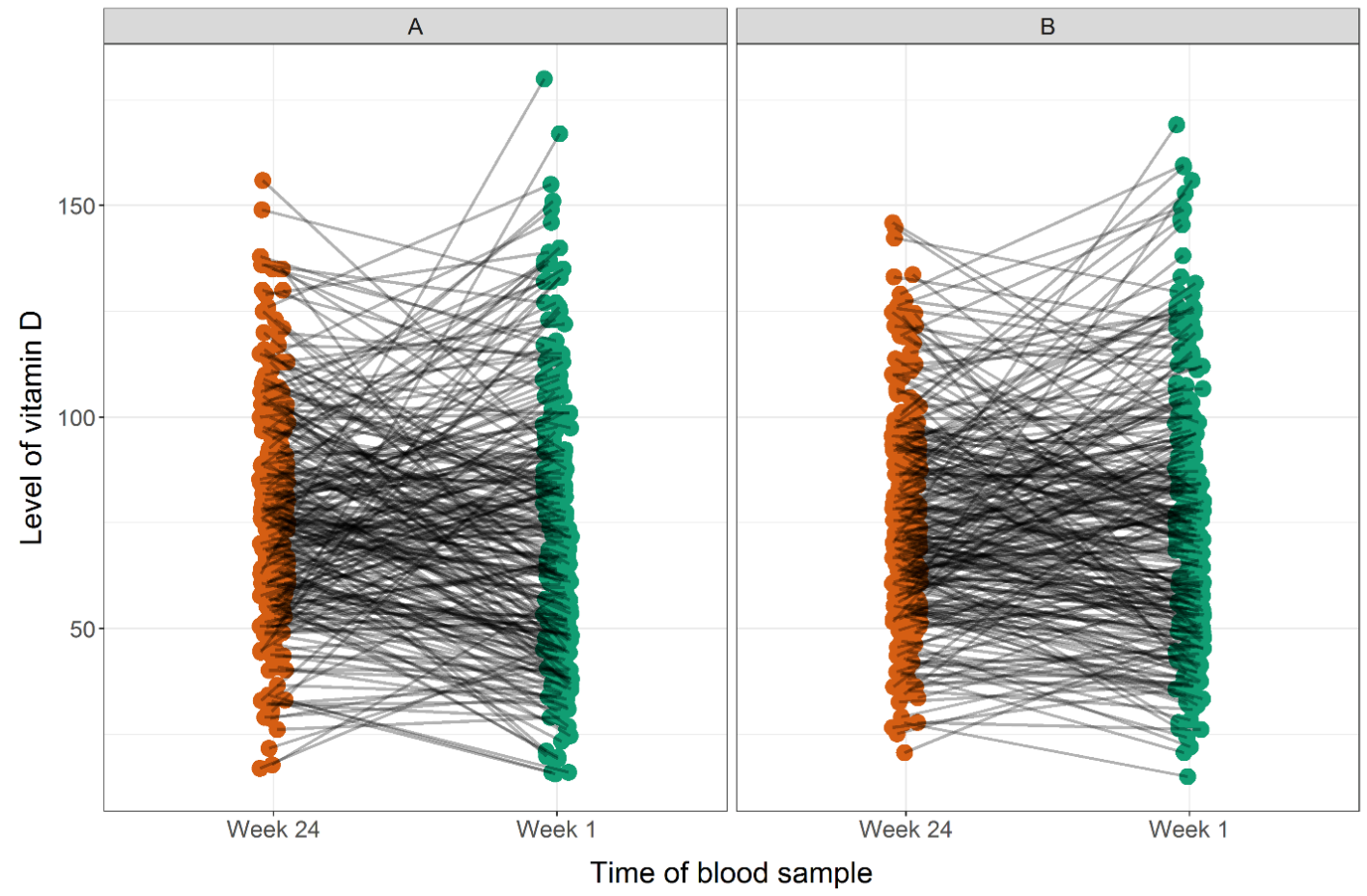

Figure 2. Correlation between maternal 25(OH)D level measured at week 24 and one week postpartum in $\mathrm{nmol} / \mathrm{L}$ unadjusted (A) and adjusted for season of blood sampling (B).

\subsection{Environmental, Dietary, and Genetic Determinants of Maternal 25(OH)D Levels}

Univariate analyses of week 24 samples showed that 25(OH)D levels were positively correlated to Caucasian origin, increasing maternal age at birth, both vitamin D SNPs, and increasing dietary intake, and negatively correlated to increasing maternal pre-pregnancy BMI. At one week postpartum, $25(\mathrm{OH}) \mathrm{D}$ levels were positively correlated to higher social circumstances, both vitamin D SNPs, and negatively correlated to maternal pre-pregnancy BMI. We did not find any other significant correlations with maternal $25(\mathrm{OH}) \mathrm{D}$ levels (Table 1 ).

Table 1. Univariate analyses of determinants for maternal season-adjusted 25(OH)D levels during pregnancy.

\begin{tabular}{|c|c|c|c|c|c|c|}
\hline & $\begin{array}{c}\text { Week } 24 \text { Gestation } \\
\beta \text {-Coefficient }(\mathrm{nmol} / \mathrm{L})\end{array}$ & $95 \%$ CI & $p$-Value & $\begin{array}{l}\text { One Week Postpartum } \\
\beta \text {-Coefficient (nmol/L) }\end{array}$ & $5 \% \mathrm{CI}$ & $p$-Value \\
\hline Maternal BMI, kg/m² & -0.74 & $\begin{array}{l}{[-1.17} \\
-0.30]\end{array}$ & 0.001 & -1.09 & $\begin{array}{l}{[-1.92 ;} \\
-0.26]\end{array}$ & 0.01 \\
\hline Gestational age, weeks & - & - & - & -1.40 & {$[-3.60 ; 0.80]$} & 0.21 \\
\hline $\begin{array}{c}\text { Caesarian section vs. vaginal } \\
\text { delivery }\end{array}$ & - & - & - & 0.01 & {$[-8.61 ; 8.63]$} & 1.00 \\
\hline Maternal age at birth, years & 0.41 & {$[0.02 ; 0.80]$} & 0.038 & 0.41 & {$[-0.41 ; 1.22]$} & 0.33 \\
\hline Maternal asthma, yes vs. no & -2.93 & {$[-6.96 ; 1.10]$} & 0.15 & -0.19 & {$[-8.11 ; 7.73]$} & 0.96 \\
\hline $\begin{array}{l}\text { Maternal smoking in third } \\
\text { trimester, yes vs. no }\end{array}$ & -1.06 & {$[-10.6 ; 8.50]$} & 0.83 & -11.78 & {$[-27.9 ; 4.32]$} & 0.15 \\
\hline $\begin{array}{l}\text { Social circumstances, PCA } \\
\text { score }\end{array}$ & 1.21 & {$[-0.57 ; 2.98]$} & 0.18 & 4.59 & {$[0.89 ; 8.29]$} & 0.015 \\
\hline $\begin{array}{c}\text { Dietary vitamin D intake, } \\
\mu \mathrm{g} / \text { day }\end{array}$ & 1.16 & {$[0.47 ; 1.84]$} & 0.001 & 0.88 & {$[-0.60 ; 2.35]$} & 0.24 \\
\hline
\end{tabular}


To examine the most important determinants of 25(OH)D levels, a multivariate forward regression analysis was made. The following variables were included in the analysis of week 24: maternal pre-pregnancy BMI, age at birth, smoking in third trimester, maternal asthma, social circumstances, diet, and the vitamin D SNPs (rs4588 and rs7041). The same variables were used for the one week postpartum analysis, but gestational age at birth and Caesarian section were also included. The final models included maternal pre-pregnancy BMI, age at birth, diet, and rs4588 for week 24, explaining $7 \%$ of the variance in $25(\mathrm{OH}) \mathrm{D}$ levels $\left(\mathrm{R}^{2}=0.07, p<0.001\right)$, and maternal pre-pregnancy BMI, social circumstances, and both vitamin D SNPs for one week postpartum, explaining $10.3 \%$ of the variance in 25(OH)D levels $\left(\mathrm{R}^{2}=0.103, p<0.001\right)$ (Table 2$)$.

Table 2. Results from final multivariate forward regression analyses of maternal season-adjusted $25(\mathrm{OH}) \mathrm{D}$ levels.

\begin{tabular}{|c|c|c|c|c|c|c|}
\hline & $\begin{array}{c}\text { Week 24 Gestation } \\
\beta \text {-Coefficient (nmol/L) }\end{array}$ & $95 \%$ CI & $p$-Value & $\begin{array}{l}\text { One Week Postpartum } \\
\beta \text {-Coefficient (nmol/L) }\end{array}$ & $95 \%$ CI & $p$-Value \\
\hline Maternal BMI, kg/m² & -0.70 & $\begin{array}{l}{[-1.20} \\
-0.25]\end{array}$ & 0.002 & -1.05 & $\begin{array}{l}{[-1.50} \\
-0.15]\end{array}$ & 0.02 \\
\hline rs 4588 & 8.30 & {$[5.00 ; 11.60]$} & $<0.001$ & 7.50 & {$[1.10 ; 18.50]$} & 0.12 \\
\hline rs7041 & - & - & - & 5.80 & $\begin{array}{l}{[-4.80} \\
10.10]\end{array}$ & 0.15 \\
\hline $\begin{array}{l}\text { Social circumstances, PCA } \\
\text { score }\end{array}$ & - & - & - & 3.70 & {$[0.60 ; 8.29]$} & 0.09 \\
\hline
\end{tabular}

To further explore the effect of the different determinants on $25(\mathrm{OH}) \mathrm{D}$ levels, a multivariate regression analysis was performed. At week 24 and one week postpartum, the environmental determinants explained $2.3 \%\left(R^{2}=0.023, p=0.002\right)$ and $1.3 \%\left(R^{2}=0.013, p=0.2\right)$ of the variance in $25(\mathrm{OH}) \mathrm{D}$, genetics explained 3.5\% $\left(\mathrm{R}^{2}=0.029, p<0.001\right)$ and $5.4 \%\left(\mathrm{R}^{2}=0.054, p<0.001\right)$, and diet explained $1.6 \%\left(R^{2}=0.016, p=0.001\right)$ and $0.2 \%\left(R^{2}=0.002, p=0.24\right)$, respectively.

\subsection{Children from COPSAC 2000}

Cord blood was available for 25(OH)D analysis in 257 (63\%) of the 411 children and $298(73 \%)$ had $25(\mathrm{OH}) \mathrm{D}$ measured at age 4 years. The median (IQR) $25(\mathrm{OH}) \mathrm{D}$ cord blood level was $40.9 \mathrm{nmol} / \mathrm{L}$ (28-55) and age 4 years was $75 \mathrm{nmol} / \mathrm{L}$ (59-91). In cord blood, $67 \%$ of the children had deficient vitamin D levels and only $8 \%$ had sufficient levels. At age 4 years, $14 \%$ had deficient and $50 \%$ had sufficient levels. Baseline characteristics of the children are given in Online Table S2.

Fewer infants with deficient 25(OH)D cord blood levels were born during summer (51\%) compared to $77 \%, 75 \%$, and $70 \%$ born during winter, spring, and autumn (Figure 3). Only $4 \%-9 \%$ had sufficient levels at all seasons, with a slight preponderance of children born during summer (9\%). At age 4 years, fewer children ( $3 \%$ ) had deficient $25(\mathrm{OH}) \mathrm{D}$ during summer compared to $17 \%, 17 \%$, and $4 \%$ during winter, spring, and autumn. Sufficient levels were measured in $36 \%-70 \%$ of the children.

When using winter as reference, cord blood levels of 25(OH)D were $12.3 \mathrm{nmol} / \mathrm{L}$ higher in children born during summer $(95 \%$ CI $[5.5 ; 19.3], p<0.001)$. For age 4 years, the levels measured during summer and autumn were $19.1 \mathrm{nmol} / \mathrm{L}(95 \% \mathrm{CI}[11.1 ; 27.1], p<0.001)$ and $12.4 \mathrm{nmol} / \mathrm{L}(95 \% \mathrm{CI}$ [4.8; 20.1], $p=0.002$ ) higher, respectively. No other seasonal differences were observed (data not shown). The 25(OH)D levels in cord blood and by age 4 years were associated both in the unadjusted and season-adjusted analyses: 0.18 (95\% CI [0.02; 0.34], $p=0.03)$ and $0.25(95 \%$ CI [0.08; 0.42], $p=0.004)$, respectively. We found an increase in the $25(\mathrm{OH}) \mathrm{D}$ levels from cord blood to age 4 years: mean difference unadjusted: $35.5 \mathrm{nmol} / \mathrm{L}(95 \%$ CI [31.7; 39.4]) and adjusted: $34.7 \mathrm{nmol} / \mathrm{L}(95 \% \mathrm{CI}$ [31.0; 38.4]) (Figure 4). 


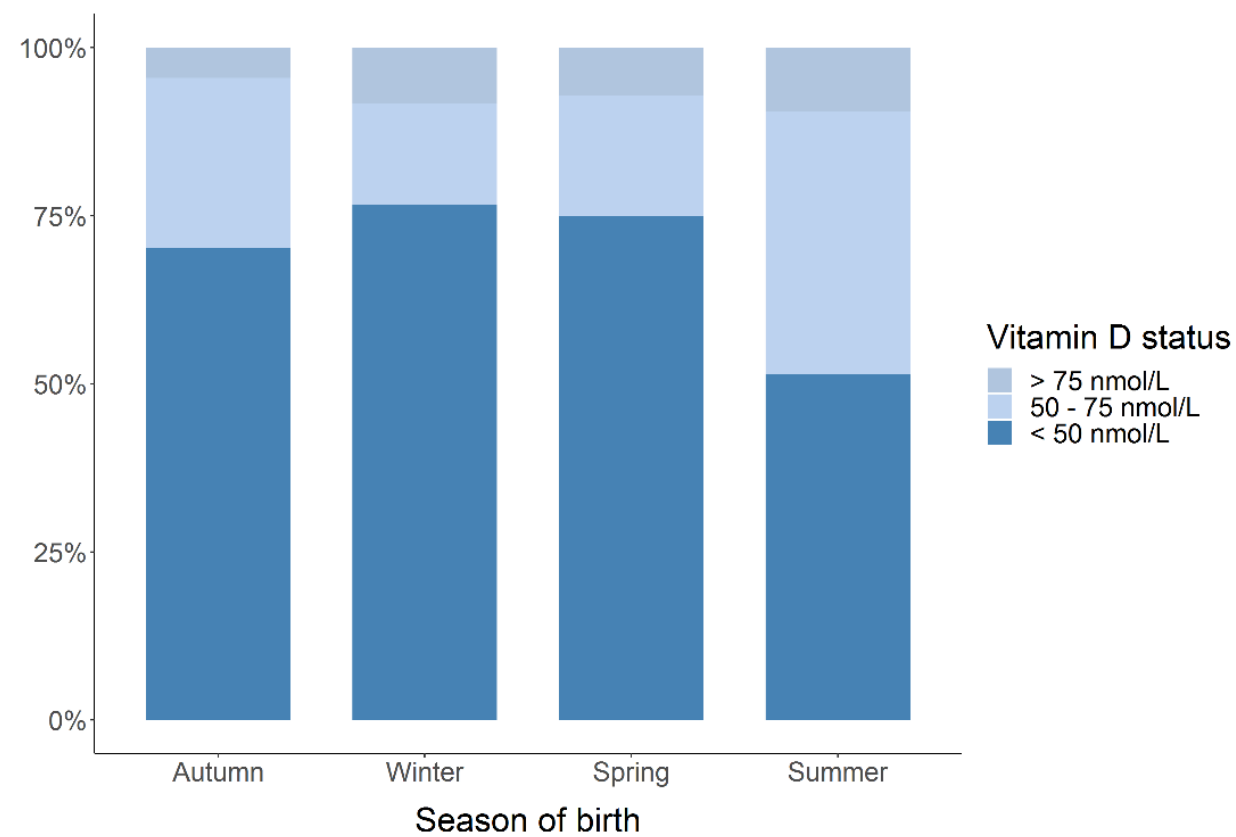

(A)

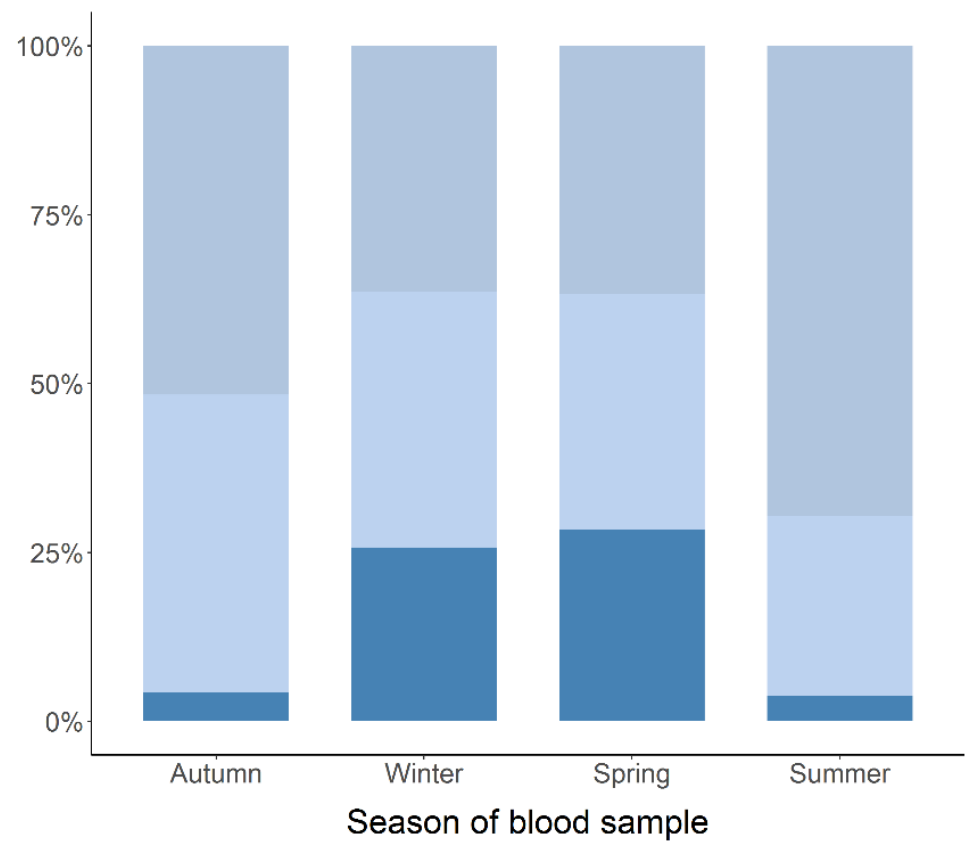

Vitamin D status

$>75 \mathrm{nmol} / \mathrm{L}$

$50-75 \mathrm{nmol} / \mathrm{L}$

$<50 \mathrm{nmol} / \mathrm{L}$

(B)

Figure 3. Child $25(\mathrm{OH}) \mathrm{D}$ status (deficient $(<50 \mathrm{nmol} / \mathrm{L})$, insufficient $(50-75 \mathrm{nmol} / \mathrm{L})$, sufficient $(>75$ $\mathrm{nmol} / \mathrm{L})$ ) measured in cord blood (A) and at 4 years (B) stratified for season of blood sampling. 


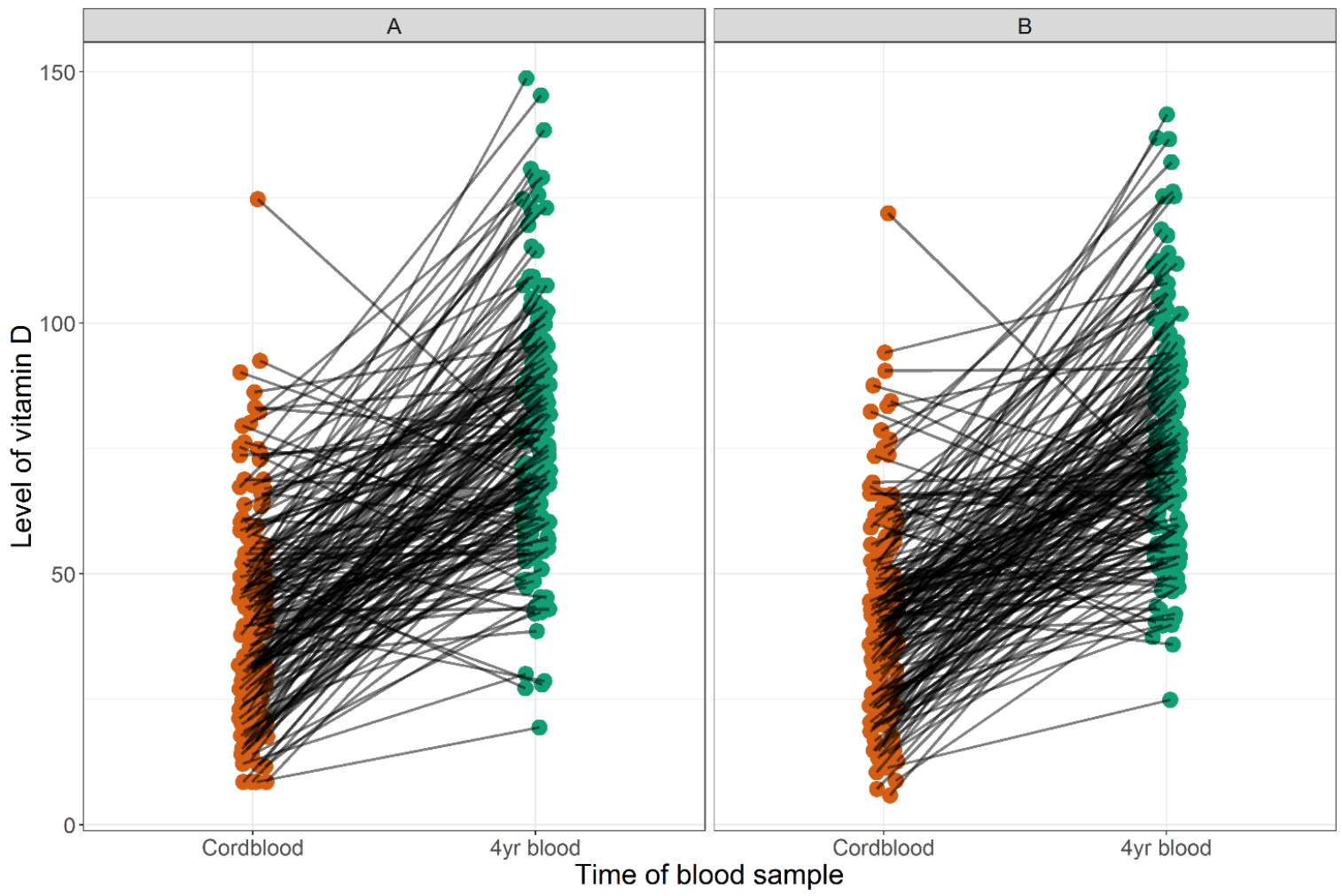

Figure 4. Correlation between cord blood and age 4 years $25(\mathrm{OH}) \mathrm{D}$ level in nmol/L unadjusted (A) and adjusted for season of blood sampling (B).

\subsection{Environmental, Dietary, and Genetic Determinants of Child 25(OH)D Levels}

In the univariate analyses, cord blood $25(\mathrm{OH}) \mathrm{D}$ level was positively correlated to maternal age at birth, the vitamin $\mathrm{D}$ genetic score, and negatively correlated to smoking during the third trimester. It was borderline positively correlated to Caucasian origin and social circumstances. At age $4,25(\mathrm{OH}) \mathrm{D}$ was positively correlated to the vitamin D genetic score, male gender, and negatively correlated to tobacco exposure (Table 3).

Table 3. Univariate analyses of determinants for cord blood and age 4 years season-adjusted 25(OH)D levels.

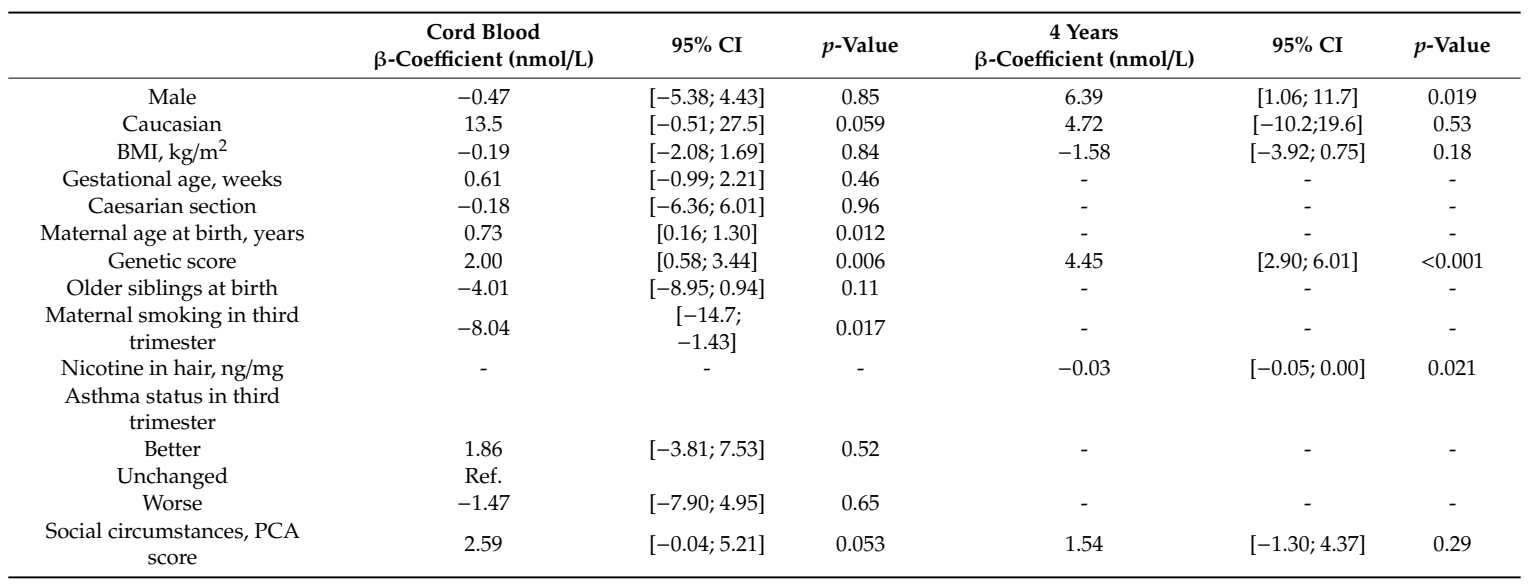

A forward multivariate regression analysis for cord blood 25(OH)D yielded a final model including maternal age at birth, smoking during third trimester, older siblings, and the vitamin D genetic score, explaining $9.6 \%\left(R^{2}=0.096, p<0.001\right)$ of the variance in $25(\mathrm{OH}) \mathrm{D}$. Particularly, having older siblings 
resulted in $8.7 \mathrm{nmol} / \mathrm{L}$ lower levels $(p=0.001)$ and smoking during the third trimester resulted in $6.5 \mathrm{nmol} / \mathrm{L}$ lower levels $(p=0.07)$ (Table 4$)$. The final forward regression model for 4 years included the vitamin D genetic score, child BMI, and gender, explaining $10.8 \%\left(R^{2}=0.108, p<0.001\right)$ of the variance. Male gender resulted in $6.7 \mathrm{nmol} / \mathrm{L}$ higher $25(\mathrm{OH}) \mathrm{D}(p=0.01)$.

Table 4. Results from final multivariate forward regression analyses of child season-adjusted 25(OH)D levels.

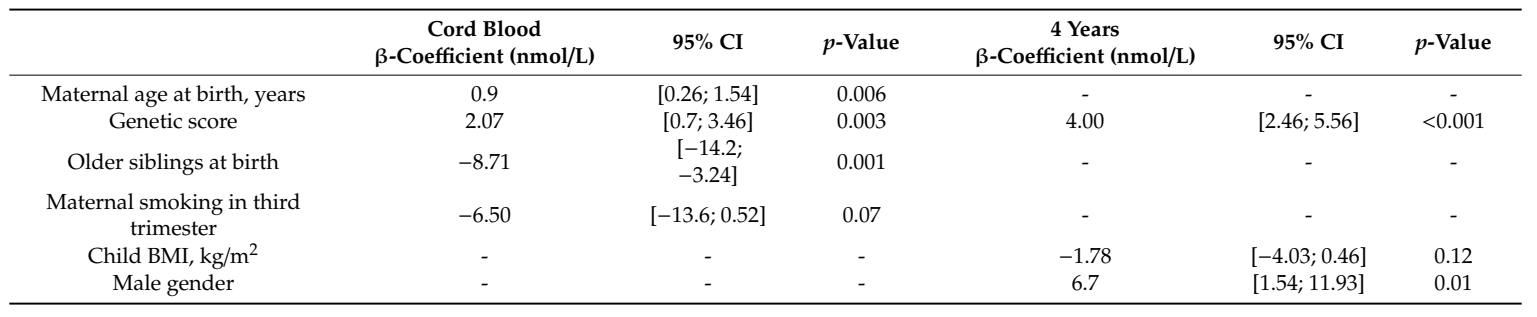

The environmental factors explained $5.2 \%\left(R^{2}=0.052, p=0.016\right)$ of the variance in $25(\mathrm{OH}) \mathrm{D}$ levels and genetics $2.9 \%\left(R^{2}=0.029, p=0.006\right)$. At 4 years, the environmental factors explained $1.8 \%$ $\left(R^{2}=0.018, p=0.105\right)$ and genetics $10.4 \%\left(R^{2}=0.104, p<0.001\right)$.

\section{Discussion}

\subsection{Primary Findings}

In both pregnant women from COPSAC $\mathrm{C}_{2010}$ and children from COPSAC $\mathrm{C}_{2000}$, we found a high prevalence of vitamin D deficiency and insufficiency despite the fact that all Danish pregnant women and children up to 2 years of age are advised to take a vitamin D supplement of $400 \mathrm{IU} / \mathrm{d}$ [38]. Less than half of the women had sufficient levels at pregnancy week 24 and one week postpartum, just $7 \%$ of the children had sufficient cord blood levels, and less than half had sufficient levels at age 4 years. The best determinants of season-adjusted $25(\mathrm{OH})$ D levels in pregnant women included pre-pregnancy BMI, social circumstances, age at birth, diet, and vitamin D genetics, whereas the best determinants in young children were maternal age at birth, older siblings, smoke exposure, child BMI, gender, and vitamin D genetics, with genetics alone explaining $2 \%-11 \%$ of the variance in $25(\mathrm{OH}) \mathrm{D}$ levels in the cohorts. These findings suggest that environment, diet, and genetics all influence $25(\mathrm{OH}) \mathrm{D}$ levels in pregnant women and young children, which is important for vitamin D supplementation strategies.

\subsection{Strengths and Limitations}

The main strength of this study is the single-center set-up with thorough longitudinal clinical phenotyping and data collection in both the COPSAC 2000 and the COPSAC 2010 cohort. All assessments were solely performed by the COPSAC research pediatricians, who ensured consistency in procedures, definitions of conditions, and data capture methods, and thereby limited inter-observer variation.

Another strength is the objective assessment of $25(\mathrm{OH}) \mathrm{D}$ levels by state-of-the-art LC-MS two times during pregnancy, in cord blood, and at age 4 years. Even though cord blood 25(OH)D level primarily reflects exposure during the third trimester and may be contaminated by maternal blood, it is considered a more accurate measure of fetal exposure compared to calculations from questionnaires on maternal diet, since only $10 \%$ of vitamin D is obtained through diet [39].

The comprehensive assessment of environmental exposure, diet, and genetics is another strength providing many relevant $25(\mathrm{OH}) \mathrm{D}$ determinants for analysis, but we lack information on certain variables, including the use of sunscreen or protective clothing, outdoor physical activity, and diet information in COPSAC 2000 . Regarding skin pigmentation, $96 \%-97 \%$ in the study groups were of Caucasian origin and we do not expect this to be of great influence; therefore, analyses were not adjusted for ethnicity. We observed that season had a major influence on 25(OH)D levels, but since it reflects the time of blood sampling rather than a long-term determinant of $25(\mathrm{OH}) \mathrm{D}$ level we adjusted 
all the risk-factor analyses for this. Regarding genetics, we chose a simple and clinically applicable approach using four genes where we had available genotype information, which have been replicated across genome-wide association studies to contribute to vitamin D levels. However, there are likely to be far more gene variants associated both with increased and decreased vitamin $D$, but these were not available in our study.

The population-based COPSAC 2010 cohort provides findings generalizable to other populations, and it would have been interesting to analyze 25(OH)D levels in the children at age 4 years to compare them to the general population. Unfortunately, we only measured $25(\mathrm{OH}) \mathrm{D}$ levels in the children in the COPSAC ${ }_{2000}$ cohort who were born to asthmatic mothers and thus not directly comparable to the general population. However, this should not affect the ability to analyze determinants of $25(\mathrm{OH}) \mathrm{D}$ levels within the cohort, and some of the findings are in line with a similar study of unselected children [40].

\subsection{Interpretation}

We found a high prevalence of vitamin D deficiency and insufficiency in both mothers and children. After adjusting for season of blood sampling, significant determinants of lower $25(\mathrm{OH}) \mathrm{D}$ levels during pregnancy were higher pre-pregnancy BMI, lower age at birth, lower social circumstances, lower dietary intake of vitamin $\mathrm{D}$, and lower genetic vitamin D score. In the children, the determinants were lower maternal age at birth, older siblings, exposure to tobacco smoking, higher pre-pregnancy $\mathrm{BMI}$, female gender, and lower genetic score. Genetics alone contributed to $2 \%-11 \%$ of the variance in $25(\mathrm{OH}) \mathrm{D}$ levels in the pregnant women and young children.

Our finding of a high prevalence of vitamin D deficiency is in line with other studies of Danish pregnant women [39] and children aged 3 months to 6 years [40]. Season of blood sampling played a major role, as we found that $25 \%$ fewer children had deficient cord blood levels if they were born during summer compared to winter and spring, which aligns with cord blood results reported from an Australian prospective birth cohort study [41]. In the COPSAC 2000 cohort, the season variation (summer vs. winter) of $25(\mathrm{OH}) \mathrm{D}$ levels in children was greater at age 4 years than in cord blood measurements, which is probably due to a greater variation of outside activity among children compared with mothers' activity in the third trimester reflected in the cord blood levels. In the COPSAC 2010 cohort, the seasonal variation of being vitamin D deficient between week 24 and one week post-partum was less profound, and this could be due to increased skin coverage and less outdoor activity in late pregnancy.

We found that $25(\mathrm{OH}) \mathrm{D}$ levels increased during childhood from birth until age 4 , which is in line with results from another birth cohort study [42], but opposite to findings from a study of healthy children observing a decrease in $25(\mathrm{OH}) \mathrm{D}$ from 3 months to 6 years [40]. An increase in vitamin D levels could be explained by different adherence to supplementation strategies or the fact that we measured $25(\mathrm{OH}) \mathrm{D}$ in cord blood, where levels are generally lower than later in childhood. Exposure to sunlight during outdoor activities is presumably the main environmental driver of the increase from birth till age 4 years, but our data also suggest that dietary and lifestyle habits associated with BMI may be of importance.

In our study, we observed associated but stable 25(OH)D levels from week 24 to one week postpartum. Previous longitudinal studies have reported both a decrease in $25(\mathrm{OH}) \mathrm{D}$ concentrations throughout pregnancy and in the period after delivery $[43,44]$ and an increase through the first, second, and third trimesters [45]. We speculate that our findings could be a result of increased adherence to the recommended supplementation guidelines, as the mothers were enrolled in a clinical trial.

We focused on vitamin D status during pregnancy and early childhood, whereas many previous studies have tried to estimate determinants of long-term vitamin D status in adulthood [46-50]. That may be more relevant as a model for assessing the risk of developing chronic diseases such as cancers, inflammatory diseases, and osteoporosis, while our model is a better predictor of vitamin D deficiency in shorter vulnerable periods where personalized vitamin D supplementation strategies would be particularly beneficial. 
We observed higher $25(\mathrm{OH}) \mathrm{D}$ in children of male sex and in children and women with lower BMI. This could be explained by males and subjects with lower BMI being more outside and more physically active, but also by the fact that vitamin $\mathrm{D}$ is fat-soluble a therefore deposited in fat tissue in girls and overweight persons. Tobacco exposure was also associated with lower child 25(OH)D level, which could be caused by other lifestyle factors found more prevalent among smokers, such as less physical activity and nutritional deficiencies. A more direct effect of tobacco exposure could include an increased hepatic metabolism of $25(\mathrm{OH}) \mathrm{D}$, as smokers have been shown to have enhanced hepatic degradation of estrogen [51]. In both the pregnant women and in the children, we found higher 25(OH)D levels with higher maternal age at birth, higher social circumstances, and in persons of Caucasian origin, which is in line with several previous studies $[40,46,47,52,53]$. The association with higher maternal age and higher social circumstances may once again be due to lifestyle factors, including higher dietary intake of vitamin D containing foods and higher adherence to the recommended daily vitamin D supplement.

In the forward regression analysis, smoke exposure and older siblings were the variables with the greatest effect on cord blood 25(OH)D when looking at the estimates. Correspondingly, at age 4 years being male had the most influence on $25(\mathrm{OH}) \mathrm{D}$ levels. However, when looking at all the environmental factors they only accounted for $2 \%-5 \%$ of the variance in $25(\mathrm{OH}) \mathrm{D}$ levels, with the greatest effect on cord blood levels. This may be due to our adjustment for seasons prior to the risk-factor analysis or due to other unknown determinants lacking in our model (e.g., outdoor physical activity).

Regarding heritability, both the pregnant women and young children had significantly higher $25(\mathrm{OH}) \mathrm{D}$ levels with higher vitamin $\mathrm{D}$ genetic score, that is, increasing number of wildtype alleles involved in the vitamin D metabolism, explaining in itself $2 \%-11 \%$ of the variance in $25(\mathrm{OH}) \mathrm{D}$. In the forward regression analysis, genetics was included in all the final models from both pregnant women and children and was the variable with greatest influence on $25(\mathrm{OH}) \mathrm{D}$ in the pregnant women, when looking at the estimates. Undoubtedly, the genetic regulation of the vitamin D pathway and levels (i.e., both increased and decreased levels) is very complex and presumably not yet completely understood. We chose a simple and clinically applicable approach using four genes where we had available genotype information, but there are likely to be far more gene variants associated with both increased and decreased vitamin D [54]. In a future study, it would be interesting to explore a wider range of gene variants, gene expression data, as well as gene-gene and gene-environment interactions contributing to trajectories of vitamin D levels during pregnancy and early childhood.

In the pregnant women, diet was significantly associated with $25(\mathrm{OH})$ levels at gestational week 24 , where the food frequency questionnaire was fulfilled. Diet was not a determinant of $25(\mathrm{OH}) \mathrm{D}$ at one week postpartum, which aligns with one previous study [53] but is in contrast to most other studies $[46,49,50,52]$, and could be explained by changing dietary habits in pregnancy. Diet was included in the week- 24 forward regression model but explained $<2 \%$ of the variance in $25(\mathrm{OH}) \mathrm{D}$.

Overall, our regression models only explained $7 \%-11 \%$ of the variance in $25(\mathrm{OH}) \mathrm{D}$ status in pregnant women and young children, which is lower than the $21 \%-40 \%$ reported in previous studies of pregnant women, adolescents, and adults [47,48,52]. This is probably because we adjusted the $25(\mathrm{OH}) \mathrm{D}$ levels for season of blood sampling to minimize this as a confounder for other risk factors, particularly when assessing determinants of $25(\mathrm{OH}) \mathrm{D}$ at several time points in the same subject [55].

\section{Conclusions}

We found a high prevalence of vitamin D deficiency during pregnancy and in early childhood, and that important determinants include environmental factors, diet, and vitamin $\mathrm{D}$ genetics. These findings may be used to identify at-risk individuals providing a more personalized approach to vitamin D supplementation advice for pregnant women and young children.

Supplementary Materials: The following are available online at http://www.mdpi.com/2227-9067/6/10/116/s1, Table S1: Baseline characteristics of pregnant women in COPSAC 2010 , Table S2: Baseline characteristics of the children in COPSAC $_{2000 .}$ 
Author Contributions: Conceptualization, H.B and B.L.C.; Methodology, H.B. and B.L.C.; Software, S.N. and B.L.C; Validation, S.N., H.B. and B.L.C.; Formal Analysis, S.N. and B.L.C.; Investigation, H.B., A.-M.M.S., C.V., B.L.C; Resources, H.B.; Data Curation, H.B.; Writing-Original Draft Preparation, A.-M.M.S. and C.V.; Writing-Review \& Editing, N.B., J.S., K.B., H.B. and B.L.C.; Visualization, B.L.C., A.-M.M.S. and C.V.; Supervision, H.B. and B.L.C.; Project Administration, H.B., K.B., J.S. and B.L.C.; Funding Acquisition, H.B., K.B., J.S. and B.L.S.

Funding: All funding received by COPSAC is listed on www.copsac.com. The Lundbeck Foundation (Grant no R16-A1694); The Ministry of Health (Grant no 903516); Danish Council for Strategic Research (Grant no 0603-00280B) and The Capital Region Research Foundation have provided core support to the COPSAC research center.

Acknowledgments: We express our deepest gratitude to the children and families of the COPSAC 2000 and COPSAC $_{2010}$ cohort study for all their support and commitment. We acknowledge and appreciate the unique efforts of the COPSAC research team.

Conflicts of Interest: The authors declare no conflict of interest.

$\begin{array}{ll}\text { Abbreviations } \\ \text { COPSAC } & \text { Copenhagen Prospective Study on Asthma in Childhood } \\ \text { 25(OH)D } & \text { 25-hydroxyvitamin D } \\ \text { SNP } & \text { single nucleotide polymorphism } \\ \text { IQR } & \text { interquartile range } \\ \text { CI } & \text { confidence interval } \\ \text { SD } & \text { standard deviation } \\ \text { AIC } & \text { Akaike information criterion }\end{array}$

\section{References}

1. Holick, M.F. Vitamin D deficiency. N. Engl. J. Med. 2007, 357, 266-281. [CrossRef] [PubMed]

2. Holick, M.F. Resurrection of vitamin D deficiency and rickets. J. Clin. Investig. 2006, 116, $2062-2072$. [CrossRef] [PubMed]

3. Feng, H.; Xun, P.; Pike, K.; Wills, A.K.; Chawes, B.L.; Bisgaard, H.; Cai, W.; Wan, Y.; He, K. In utero exposure to 25-hydroxyvitamin $\mathrm{D}$ and risk of childhood asthma, wheeze, and respiratory tract infections: A meta-analysis of birth cohort studies. J. Allergy Clin. Immunol. 2017, 139, 1508-1517. [CrossRef] [PubMed]

4. Hyppönen, E.; Läärä, E.; Reunanen, A.; Järvelin, M.-R.; Virtanen, S.M. Intake of vitamin D and risk of type 1 diabetes: A birth-cohort study. Lancet 2001, 358, 1500-1503. [CrossRef]

5. Krause, R.; Bühring, M.; Hopfenmüller, W.; Holick, M.F.; Sharma, A.M. Ultraviolet B and blood pressure. Lancet 1998, 352, 709-710. [CrossRef]

6. Dobnig, H.; Pilz, S.; Scharnagl, H.; Renner, W.; Seelhorst, U.; Wellnitz, B.; Kinkeldei, J.; Boehm, B.O.; Weihrauch, G.; Maerz, W. Independent association of low serum 25-hydroxyvitamin d and 1,25-dihydroxyvitamin d levels with all-cause and cardiovascular mortality. Arch. Intern. Med. 2008, 168, 1340-1349. [CrossRef]

7. Ginde, A.A.; Scragg, R.; Schwartz, R.S.; Camargo, C.A. Prospective study of serum 25-hydroxyvitamin D level, cardiovascular disease mortality, and all-cause mortality in older U.S. adults. J. Am. Geriatr. Soc. 2009, 57, 1595-1603. [CrossRef]

8. Wortsman, J.; Matsuoka, L.Y.; Chen, T.C.; Lu, Z.; Holick, M.F. Decreased bioavailability of vitamin D in obesity. Am. J. Clin. Nutr. 2000, 72, 690-693. [CrossRef]

9. Garland, C.F.; Comstock, G.W.; Garland, F.C.; Helsing, K.J.; Shaw, E.K.; Gorham, E.D. Serum 25-hydroxyvitamin D and colon cancer: Eight-year prospective study. Lancet 1989, 2, 1176-1178. [CrossRef]

10. Gorham, E.D.; Garland, C.F.; Garland, F.C.; Grant, W.B.; Mohr, S.B.; Lipkin, M.; Newmark, H.L.; Giovannucci, E.; Wei, M.; Holick, M.F. Vitamin D and prevention of colorectal cancer. J. Steroid Biochem. Mol. Biol. 2005, 97, 179-194. [CrossRef]

11. Hanchette, C.L.; Schwartz, G.G. Geographic patterns of prostate cancer mortality. Evidence for a protective effect of ultraviolet radiation. Cancer 1992, 70, 2861-2869. [CrossRef]

12. Grant, W.B. An estimate of premature cancer mortality in the U.S. due to inadequate doses of solar ultraviolet-B radiation. Cancer 2002, 94, 1867-1875. [CrossRef] [PubMed] 
13. The Association of Solar Ultraviolet B (UVB) with Reducing Risk of Cancer: Multifactorial Ecologic Analysis of Geographic Variation in Age-Adjusted Cancer Mortality Rates. Available online: https://www.ncbi.nlm.nih.gov/pubmed/?term=The+association+of+solar+ultraviolet+B+(UVB)+with+ reducing+risk+of+cancer\%3A+multifactorial+ecologic+analysis+of+geographic+variation+in+ageadjusted+cancer+mortality+rates (accessed on 2 July 2019).

14. Giovannucci, E.; Liu, Y.; Rimm, E.B.; Hollis, B.W.; Fuchs, C.S.; Stampfer, M.J.; Willett, W.C. Prospective study of predictors of vitamin D status and cancer incidence and mortality in men. J. Natl. Cancer Inst. 2006, 98, 451-459. [CrossRef] [PubMed]

15. Munger, K.L.; Zhang, S.M.; O’Reilly, E.; Hernán, M.A.; Olek, M.J.; Willett, W.C.; Ascherio, A. Vitamin D intake and incidence of multiple sclerosis. Neurology 2004, 62, 60-65. [CrossRef] [PubMed]

16. Dawson-Hughes, B.; Heaney, R.P.; Holick, M.F.; Lips, P.; Meunier, P.J.; Vieth, R. Estimates of optimal vitamin D status. Osteoporos Int. 2005, 16, 713-716. [CrossRef] [PubMed]

17. Thomas, M.K.; Lloyd-Jones, D.M.; Thadhani, R.I.; Shaw, A.C.; Deraska, D.J.; Kitch, B.T.; Vamvakas, E.C.; Dick, I.M.; Prince, R.L.; Finkelstein, J.S. Hypovitaminosis D in medical inpatients. N. Engl. J. Med. 1998, 338, 777-783. [CrossRef] [PubMed]

18. Gallagher, J.C.; Sai, A.J. Vitamin D Insufficiency, Deficiency, and Bone Health. J. Clin. Endocrinol. Metab. 2010, 95, 2630-2633. [CrossRef]

19. Mansbach, J.M.; Ginde, A.A.; Camargo, C.A. Serum 25-hydroxyvitamin D levels among US children aged 1 to 11 years: Do children need more vitamin D? Pediatrics 2009, 124, 1404-1410. [CrossRef]

20. Bodnar, L.M.; Simhan, H.N.; Powers, R.W.; Frank, M.P.; Cooperstein, E.; Roberts, J.M. High Prevalence of Vitamin D Insufficiency in Black and White Pregnant Women Residing in the Northern United States and Their Neonates. J. Nutr. 2007, 137, 447-452. [CrossRef]

21. Rovner, A.J.; O'Brien, K.O. Hypovitaminosis D among healthy children in the United States: A review of the current evidence. Arch Pediatr. Adolesc. Med. 2008, 162, 513-519. [CrossRef]

22. Lee, J.M.; Smith, J.R.; Philipp, B.L.; Chen, T.C.; Mathieu, J.; Holick, M.F. Vitamin D deficiency in a healthy group of mothers and newborn infants. Clin. Pediatr. (Phila.) 2007, 46, 42-44. [CrossRef] [PubMed]

23. Chawes, B.L.; Bønnelykke, K.; Jensen, P.F.; Schoos, A.-M.M.; Heickendorff, L.; Bisgaard, H. Cord blood 25(OH)-vitamin D deficiency and childhood asthma, allergy and eczema: The COPSAC 2000 birth cohort study. PLoS ONE 2014, 9, e99856. [CrossRef] [PubMed]

24. Ahn, J.; Yu, K.; Stolzenberg-Solomon, R.; Simon, K.C.; McCullough, M.L.; Gallicchio, L.; Jacobs, E.J.; Ascherio, A.; Helzlsouer, K.; Jacobs, K.B.; et al. Genome-wide association study of circulating vitamin D levels. Hum. Mol. Genet. 2010, 19, 2739-2745. [CrossRef] [PubMed]

25. Wang, T.J.; Zhang, F.; Richards, J.B.; Kestenbaum, B.; van Meurs, J.B.; Berry, D.; Kiel, D.P.; Streeten, E.A.; Ohlsson, C.; Koller, D.L.; et al. Common genetic determinants of vitamin D insufficiency: A genome-wide association study. Lancet 2010, 376, 180-188. [CrossRef]

26. Carpenter, T.O.; Zhang, J.H.; Parra, E.; Ellis, B.K.; Simpson, C.; Lee, W.M.; Balko, J.; Fu, L.; Wong, B.Y.-L.; Cole, D.E.C. Vitamin D binding protein is a key determinant of 25 -hydroxyvitamin D levels in infants and toddlers. J. Bone Miner. Res. 2013, 28, 213-221. [CrossRef]

27. Navas-Nazario, A.; Li, F.Y.; Shabanova, V.; Weiss, P.; Cole, D.E.C.; Carpenter, T.O.; Bazzy-Asaad, A. Effect of vitamin D-binding protein genotype on the development of asthma in children. Ann. Allergy Asthma Immunol. 2014, 112, 519-524. [CrossRef]

28. Bisgaard, H. The Copenhagen Prospective Study on Asthma in Childhood (COPSAC): Design, rationale, and baseline data from a longitudinal birth cohort study. Ann. Allergy Asthma Immunol. 2004, 93, 381-389. [CrossRef]

29. Bisgaard, H.; Hermansen, M.N.; Loland, L.; Halkjaer, L.B.; Buchvald, F. Intermittent inhaled corticosteroids in infants with episodic wheezing. N. Engl. J. Med. 2006, 354, 1998-2005. [CrossRef]

30. Bisgaard, H.; Hermansen, M.N.; Buchvald, F.; Loland, L.; Halkjaer, L.B.; Bønnelykke, K.; Brasholt, M.; Heltberg, A.; Vissing, N.H.; Thorsen, S.V.; et al. Childhood asthma after bacterial colonization of the airway in neonates. N. Engl. J. Med 2007, 357, 1487-1495. [CrossRef]

31. Bisgaard, H.; Vissing, N.H.; Carson, C.G.; Bischoff, A.L.; Følsgaard, N.V.; Kreiner-Møller, E.; Chawes, B.L.K.; Stokholm, J.; Pedersen, L.; Bjarnadóttir, E.; et al. Deep phenotyping of the unselected COPSAC 2010 birth cohort study. Clin. Exp. Allergy 2013, 43, 1384-1394. [CrossRef] 
32. Chawes, B.L.; Bønnelykke, K.; Stokholm, J.; Vissing, N.H.; Bjarnadóttir, E.; Schoos, A.-M.M.; Wolsk, H.M.; Pedersen, T.M.; Vinding, R.K.; Thorsteinsdóttir, S.; et al. Effect of Vitamin D3 Supplementation During Pregnancy on Risk of Persistent Wheeze in the Offspring: A Randomized Clinical Trial. Jama 2016, 315, 353-361. [CrossRef] [PubMed]

33. Bisgaard, H.; Stokholm, J.; Chawes, B.L.; Vissing, N.H.; Bjarnadóttir, E.; Schoos, A.-M.M.; Wolsk, H.M.; Pedersen, T.M.; Vinding, R.K.; Thorsteinsdóttir, S.; et al. Fish Oil-Derived Fatty Acids in Pregnancy and Wheeze and Asthma in Offspring. N. Engl. J. Med. 2016, 375, 2530-2539. [CrossRef] [PubMed]

34. Højskov, C.S.; Heickendorff, L.; Møller, H.J. High-throughput liquid-liquid extraction and LCMSMS assay for determination of circulating $25(\mathrm{OH})$ vitamin D3 and D2 in the routine clinical laboratory. Clin. Chim. Acta 2010, 411, 114-116. [CrossRef] [PubMed]

35. Maunsell, Z.; Wright, D.J.; Rainbow, S.J. Routine Isotope-Dilution Liquid Chromatography-Tandem Mass Spectrometry Assay for Simultaneous Measurement of the 25-Hydroxy Metabolites of Vitamins D2 and D3. Clin. Chem. 2005, 51, 1683-1690. [CrossRef] [PubMed]

36. Sørensen, M.; Bisgaard, H.; Stage, M.; Loft, S. Biomarkers of exposure to environmental tobacco smoke in infants. Biomarkers 2007, 12, 38-46. [CrossRef]

37. Olsen, S.F.; Mikkelsen, T.B.; Knudsen, V.K.; Orozova-Bekkevold, I.; Halldórsson, T.I.; Strøm, M.; Østerdal, M.L. Data collected on maternal dietary exposures in the Danish National Birth Cohort. Paediatr. Perinat. Epidemiol. 2007, 21, 76-86. [CrossRef]

38. Sundhedsstyrelsen. Available online: https://www.sst.dk/da (accessed on 21 August 2019).

39. Sichert-Hellert, W.; Wenz, G.; Kersting, M. Vitamin intakes from supplements and fortified food in German children and adolescents: Results from the DONALD study. J. Nutr. 2006, 136, 1329-1333. [CrossRef]

40. Carpenter, T.O.; Herreros, F.; Zhang, J.H.; Ellis, B.K.; Simpson, C.; Torrealba-Fox, E.; Kim, G.J.; Savoye, M.; Held, N.A.; Cole, D.E.C. Demographic, dietary, and biochemical determinants of vitamin D status in inner-city children. Am. J. Clin. Nutr. 2012, 95, 137-146. [CrossRef]

41. Jones, A.P.; Palmer, D.; Zhang, G.; Prescott, S.L. Cord blood 25-hydroxyvitamin D3 and allergic disease during infancy. Pediatrics 2012, 130, e1128-e1135. [CrossRef]

42. Wang, G.; Liu, X.; Bartell, T.R.; Pearson, C.; Cheng, T.L.; Wang, X. Vitamin D Trajectories from Birth to Early Childhood and Elevated Systolic Blood Pressure During Childhood and Adolescence. Hypertension 2019, 74, 421-430. [CrossRef]

43. Zhang, J.Y.; Lucey, A.J.; Horgan, R.; Kenny, L.C.; Kiely, M. Impact of pregnancy on vitamin D status: A longitudinal study. Br. J. Nutr. 2014, 112, 1081-1087. [CrossRef] [PubMed]

44. Narchi, H.; Kochiyil, J.; Zayed, R.; Abdulrazzak, W.; Agarwal, M. Maternal vitamin D status throughout and after pregnancy. J Obstet. Gynaecol. 2010, 30, 137-142. [CrossRef]

45. Lawlor, D.A.; Wills, A.K.; Fraser, A.; Sayers, A.; Fraser, W.D.; Tobias, J.H. Association of maternal vitamin D status during pregnancy with bone-mineral content in offspring: A prospective cohort study. Lancet 2013, 381, 2176-2183. [CrossRef]

46. Chan, J.; Jaceldo-Siegl, K.; Fraser, G.E. Determinants of serum 25 hydroxyvitamin D levels in a nationwide cohort of blacks and non-Hispanic whites. Cancer Causes Control 2010, 21, 501-511. [CrossRef] [PubMed]

47. Bertrand, K.A.; Giovannucci, E.; Liu, Y.; Malspeis, S.; Eliassen, A.H.; Wu, K.; Holmes, M.D.; Laden, F.; Feskanich, D. Determinants of plasma 25-hydroxyvitamin D and development of prediction models in three US cohorts. Br. J. Nutr. 2012, 108, 1889-1896. [CrossRef] [PubMed]

48. Millen, A.E.; Wactawski-Wende, J.; Pettinger, M.; Melamed, M.L.; Tylavsky, F.A.; Liu, S.; Robbins, J.; LaCroix, A.Z.; LeBoff, M.S.; Jackson, R.D. Predictors of serum 25-hydroxyvitamin D concentrations among postmenopausal women: The Women's Health Initiative Calcium plus Vitamin D clinical trial. Am. J. Clin. Nutr. 2010, 91, 1324-1335. [CrossRef]

49. Hill, T.R.; Cotter, A.A.; Mitchell, S.; Boreham, C.A.; Dubitzky, W.; Murray, L.; Strain, J.J.; Flynn, A.; Robson, P.J.; Wallace, J.M.W.; et al. Vitamin D status and its determinants in adolescents from the Northern Ireland Young Hearts 2000 cohort. Br. J. Nutr. 2008, 99, 1061-1067. [CrossRef]

50. Hirani, V.; Mosdøl, A.; Mishra, G. Predictors of 25-hydroxyvitamin D status among adults in two British national surveys. Br. J. Nutr. 2009, 101, 760-764. [CrossRef]

51. Jensen, G.F.; Meinecke, B.; Boesen, J.; Transbøl, I. Does 1,25(OH)2D3 accelerate spinal bone loss? A controlled therapeutic trial in 70-year-old women. Clin. Orthop. Relat. Res. 1985, 215-221. 
52. Bjørn Jensen, C.; Thorne-Lyman, A.L.; Vadgård Hansen, L.; Strøm, M.; Odgaard Nielsen, N.; Cohen, A.; Olsen, S.F. Development and validation of a vitamin D status prediction model in Danish pregnant women: A study of the Danish National Birth Cohort. PLoS ONE 2013, 8, e53059. [CrossRef]

53. Rodriguez, A.; Santa Marina, L.; Jimenez, A.M.; Esplugues, A.; Ballester, F.; Espada, M.; Sunyer, J.; Morales, E. Vitamin D Status in Pregnancy and Determinants in a Southern European Cohort Study. Paediatr. Perinat. Epidemiol. 2016, 30, 217-228. [CrossRef] [PubMed]

54. Jiang, X.; O’Reilly, P.F.; Aschard, H.; Hsu, Y.-H.; Richards, J.B.; Dupuis, J.; Ingelsson, E.; Karasik, D.; Pilz, S.; Berry, D.; et al. Genome-wide association study in 79,366 European-ancestry individuals informs the genetic architecture of 25-hydroxyvitamin D levels. Nat. Commun. 2018, 9, 260. [CrossRef] [PubMed]

55. Bruinse, H.W.; van den Berg, H. Changes of some vitamin levels during and after normal pregnancy. Eur. J. Obstet. Gynecol. Reprod. Biol. 1995, 61, 31-37. [CrossRef]

(C) 2019 by the authors. Licensee MDPI, Basel, Switzerland. This article is an open access article distributed under the terms and conditions of the Creative Commons Attribution (CC BY) license (http://creativecommons.org/licenses/by/4.0/). 